\title{
Effect of Thyponium flageliforme in Combination with Curcuma zedoaria and Phyllanthus niruri in Expression of Protein Estrogen Receptor and Caspase- 9 on Breast Cancer Mice
}

\author{
Eni Widayati ${ }^{1 *}$, Chodidjah $^{2}$ and Taufiqurrachman Nasihun ${ }^{3}$ \\ 'Department of Chemistry, Medical Faculty, Sultan Agung Islamic University, \\ Jawa Tengah - 50112, Indonesia \\ 2Department of Anatomy, Medical Faculty, Sultan Agung Islamic University, \\ Jawa Tengah - 50112, Indonesia \\ ${ }^{3}$ Department of Biochemistry, Sultan Agung Islamic University, Semarang, \\ Jawa Tengah - 50112, Indonesia
}

\begin{abstract}
Introduction: Incidence of breast cancer is high and constitutes a significant cause of female mortality. One of breast cancer type is Estrogen and Progesteron Receptor (ER and PR) positive, therefore affected by estrogen and progesteron concentration. Treatment of Thyponium flageliforme in combination with Curcuma zedoaria, and Phyllanthus niruri (TCP) have been proven capable of inhibiting tumor cells proliferation. Objective: To evaluate the expression of protein estrogen receptor and caspase-9 in $\mathrm{C} 3 \mathrm{H}$ mice were inoculated with adenocarcinoma cells. Methods: 18 mice were inoculated with one million cells of breast adenocarcinoma per mouse and assigned into three groups. TCP with dosage 85 and $125 \mathrm{mg}$ were treated for 21 days to evaluate the expression of protein estrogen receptor and caspase- 9 measured by immuno-histochemical staining. Results: Mann Whitney analysis demonstrated that expression of protein estrogen receptor and caspase-9 in TCP 125 was significant $(p<0.05)$. Conclusion: Expression of protein estrogen receptor was decreased and caspase- 9 expression was increased by TCP administration.
\end{abstract}

Keywords: Breast Cancer, Caspase9, Combination of Herbal Extracts, Estrogen Receptors

\section{Introduction}

Breast cancer is the most common female cancer and the second most common cause of mortality in women ${ }^{1}$. It was estimated that there were 1.67 million new cases and 0.52 million deaths from breast cancer in 2012, accounting for $25.1 \%$ of all new cancer cases and $14.7 \%$ of all cancer deaths in women, respectively ${ }^{2}$. Breast cancer contributes to $28.7 \%$ of total cancer population ${ }^{3}$. In 2025 , breast cancer will account for an estimated 11.5 million deaths among women worldwide if there is no effective prevention effort. To date, treatment of breast cancer is complex; including surgery, as a crucial approach but not the only step. Surgery has an important role in the treatment of cancer particularly the primary cancer. In selected cases, patients with metastatic cancer also obtain benefit from surgical treatment. In addition to surgery, another treatment of breast cancer is radiotherapy and chemotherapy ${ }^{4}$; however, these treatments have not been yet effective. Therefore other treatment model or adjuvant therapy taken from medicinal plants should be considered. 
Since 1990, incidence rate of breast cancer levelled off with a decrease of 3.5 percent per year from 2001 to $2004^{5,6}$. In this period, breast cancer mortality rates have also declined to $24 \%$ with the biggest impact among women with Estrogen Receptor (ER)-positive disease ${ }^{6-8}$. The decline in breast cancer mortality was attributable to the combination of early detection with screening programs and the efficacious adjuvant systemic therapy ${ }^{5}$. In Indonesia Thyponium flageliforme (TF), Curcuma zedoaria (CZ), and Phyllanthus niruri (PN), also known as TCP have been proven capable of inhibiting the breast cancer cells progression in $v i v o^{9}$. However, the role of estrogen receptor and caspase- 9 in inhibition of breast cancer progression following TCP treatment remains unclear. Therefore, TCP effect on estrogen receptor and caspase-9 in breast cancer need to be elucidated, before being considered as adjuvant therapy to breast cancer.

Estrogen is a class of sex steroid hormone, synthesized from cholesterol and secreted primarily by the ovaries ${ }^{10}$. Estrogen exposure has been known as breast cancer risk factor in women. Some studies showed that prolonged exposure to higher concentrations of endogenous estrogen; controlled and modulated by menarche, pregnancy, and menopause; increase the risk of breast cancer ${ }^{5,11}$. Breast cancer is a heterogeneous disease that is characterized by high proliferation, abnormal growth, and immortality of the epithelial cells of the breast ${ }^{6}$. In addition to steroid hormone, estrogen is also a growth factor, constituting the major inducer of the breast cancer, through signalling pathways responsible for highly mitogenic and anti-apoptotic activities ${ }^{12}$. The effects of $17-\beta$-estradiol (E2) are mediated particularly by the Estrogen Receptors $\alpha(E R-\alpha)$ and in the certain extent is Estrogen Receptor $\beta$ (ER- $\beta$ ). Both of which are produced by different genes and function as ligandactivated transcription factors ${ }^{13}$. Estrogen receptors are proteins found in the intracellular of breast cancer cells, which play a pivotal role in the cell proliferation ${ }^{14}$. The ER- $\alpha$ and ER- $\beta$ are the members of the nuclear hormone receptor super family, which form homodimers and bind specific DNA elements named Estrogen Responsive Elements (ERE) in the target gene promoters ${ }^{14}$. According to Lerner LJ, estrogen's pivotal role in mammary carcinogenesis was demonstrated in 1990. His study indicated that surgically removal of the ovaries was followed by reduced levels of circulating hormones and remarkable improvement in women with breast cancer ${ }^{15}$. In contrary, exposing the breast to higher amounts of estrogen, can stimulate the development of cancer ${ }^{16,17}$. Estrogen receptors particularly ER- $\alpha$ posses a pivotal role in the breast cancer cells proliferation, whereas caspase-9 is a cytoplasmic protein acting as an initiator of apoptosis. Accordingly, decreased expression of ER may inhibit proliferation and induce apoptosis. Numerous studies indicated that caspases are a family of cysteine proteases divided into two classes: group of initiator caspases like as caspase-2,8,9,10 and group of executioner caspases such as caspase-3,6,7 ${ }^{18}$. Moreover, flavonoids present in the plant extracts from the heterogeneous family are functionally related and have been proven capable of inducing apoptosis due to modification of the relationship between the cytosol levels of Bax and Bcl-2 and alteration of mitochondria permeability potential (intrinsic). However, apoptosis can also occur via extrinsic pathways as it is controlled by TRAIL and TNFa respectively ${ }^{19}$.

AS reported by Lee SH et al. the treatment with PN alone was capable of inducing cancer cell apoptosis via increasing activity of caspase-3 and caspase-7. In vitro study of human lung (A549) and breast (MCF, -7) cancers, also indicated that $\mathrm{PN}$ was able to inhibits cancer metastasis by inhibiting tumor cell invasion and migration ${ }^{20}$. There are numerous reports that isocurcumenol contained in $\mathrm{CZ}$ is capable of inhibiting the proliferation, increased apoptosis and the expression of caspase- 3 in cancer cells ${ }^{21}$. In addition, hexan fraction of CZ namely curzerenon, and alismol are able to inhibit the MCF7 proliferation and have a cytotoxic effect in MCF7 cell culture ${ }^{22}$. Moreover, a study on TF syrup at the dose of $40 \mathrm{mg} / \mathrm{ml}$ and $80 \mathrm{mg} / \mathrm{ml}$ given in 0.2 cc orally once daily for 25 days in $\mathrm{C} 3 \mathrm{H}$ mice tumor indicated lowering of Her2neu protein and Ki-67 expression, and tumor volume ${ }^{9}$. However, the tumor volume could not be completely eliminated ${ }^{10}$. These previous data pointed out that, administration of TF, CZ, and PN individually is not effective to eliminate tumor completely, despite its capability to suppress protein proliferation (Ki-67) and increased expression of proteins pro-apoptosis (caspase-3,7). Therefore, administration of the TF in combination with $\mathrm{CZ}$, and $\mathrm{PN}$ (TCP) constitute a rational approach to eliminate tumor through reduce estrogen receptors and elevate cells apoptosis. This 
present study was aimed to evaluate the effect of TCP on estrogen receptor and caspase- 9 protein expression.

\section{Methods}

In the experimental study with a post-test only control group design, $18 \mathrm{C} 3 \mathrm{H}$ mice were inoculated with one million cells of breast adenocarcinoma per mouse, randomly allocated into 3 groups. 1. Negative control group (Neg-G), received $0.2 \mathrm{ml}$ of aquadest. 2. Group of TCP-85, got extract of TF $40 \mathrm{mg} / \mathrm{BW}$, in combination with CZ $42 \mathrm{mg} / \mathrm{BW}$ and PN 1.89/BW. 3. Group of TCP125 , got extract of TF $80 \mathrm{mg} / \mathrm{BW}$, in combination with $\mathrm{CZ} 42 \mathrm{mg} / \mathrm{BW}$ and $\mathrm{PN} 1.89 / \mathrm{BW}$. The treatment was given orally once daily for 21 consecutive days. At the end of treatment (day 22), histophatological tumor tissues preparation were made and stained by immunohistochemical method. The tissue preparation then view under the light microscope with 400x magnification. This study was approved by Ethics Committee of the Faculty of Medicine, Sultan Agung Islamic University Semarang.

\subsection{TCP Extract}

TCP obtained from market was washed, sliced, air dried, and powdered. $200 \mathrm{~g}$ of dry powder of TCP was extracted by Soxhlet method with ethanol $90 \%$ as a solvent. The extract was concentrated using a rotary evaporator. The TCP extract (50g) was used to make syrup. The extraction process was carried out in the Chemical laboratory of Sultan Agung Islamic University Medical Faculty, Semarang, Central Java Indonesia.

\subsection{Tumor Inoculation}

One million of adenocarcinoma breast cancer cells were inoculated by subcutaneous injection of $0.2 \mathrm{ml}$ tumor pulp into fat pad of mice. The tumor pulp was made from a breast cancer originated from a donor mouse that had been sacrificed. The cancer cells were powdered, then physiologic saline added in a ratio of 1:1.

\subsection{Immunohistochemistry Stained Slides Preparation}

The immunohistochemical stained slides were prepared by deparaffining, i.e., immersion of the tissue sections in xylol for 2 minutes, then in absolute ethanol, 95\% ethanol, $80 \%$ ethanol, and $70 \%$ ethanol respectively for 1 minute, and then running water for 10-15 minutes. After immersion in $3 \%$ of $\mathrm{H}_{2} \mathrm{O}_{2}$ for 30 minutes, the slides were washed three times in PBS for 2 minutes each, placed in $0.25 \%$ trypsin for 6 minutes at $37^{\circ} \mathrm{C}$, and then washed again in PBS three times for 2 minutes each. Then the slides were immersed in the solutions of monoclonal antibody anti-caspase- 9 and anti estrogen receptor for 30 minutes. Subsequently the slides were washed three times in PBS for 2 minutes of each, then placed in peroxidase-labeled secondary antibody solution, then washed three times in PBS for 2 minutes each, placed in chromogen substrate solution for 5 minutes, then washed three times in PBS for 2 minutes each and washed in distilled water. Finally, the slides were immersed in Mayer Hematoxylin stain for 6 minutes, washed in running water, and dehydrated, cleared, and mounted.

\subsection{Assessment of Estrogen Receptor and Caspase-9}

Expression of protein estrogen receptors and caspase- 9 as indicator of receptor existence and cellular apoptosis respectively, were determined by Alred Score methods. The number of estrogen receptor and caspase- 9 expressions was identified by light microscopy at 400x magnifications in 10 fields of view of each slide. Two hundred cells in each field were counted and determined the number of estrogen receptor and caspase- 9 expression. The expression of estrogen receptor was characterized by the brown colour in nucleus, whereas caspase- 9 was marked by the brown colour in both cytoplasm and nucleus.

\subsection{Statistical Analysis}

The total expression number of estrogen receptor and caspase- 9 were presented as the mean \pm SEM. Differences between groups were analyzed for statistical significance, using Kurskall Wallis and followed by Mann Whitney with the significance level of $95 \%$.

\section{Results}

After one-week adenocarcinoma cell inoculation in mice, all mice suffered from tumor with the size of about $2 \mathrm{~mm} \times 2 \mathrm{~mm} \times 1 \mathrm{~mm}$. The expression of estrogen reseptor and caspase- 9 after TCP treatment of 21 days, are shown in Table 1. 
Table 1: The mean estrogen receptors and caspase-9 expression after TCP treatment

\begin{tabular}{lcccc}
\hline \multirow{2}{*}{ Variables } & \multicolumn{3}{c}{ Groups } & P (Kurskal Wallis) \\
\cline { 2 - 4 } & $\begin{array}{c}\text { Neg-G } \\
(\mathbf{n}=6 ; \pm \text { SD })\end{array}$ & $\begin{array}{c}\text { TCP85-G } \\
(\mathbf{n}=6 ; \pm \text { SD) }\end{array}$ & $\begin{array}{c}\text { TCP125-G } \\
(\mathbf{n}=6 ; \pm \text { SD) }\end{array}$ & 0.004 \\
\hline Estrogen Rec (\%) & $6.8 \pm 0,20$ & $6.6 \pm 0.24$ & $4.2 \pm 0.20$ & 0.004 \\
Caspase-9 (\%) & $6.2 \pm 0.20$ & $6.2 \pm 0.20$ & $8.2 \pm 0.20$ & 0 \\
\hline
\end{tabular}

The protein estrogen receptor expression was highest in negative control group, followed by TCP85 group, and the lowest in TCP125 group. On the other hand, expression of caspase- 9 in negative control group and TCP85 were similar, but higher in group of TCP125. Kurskall Wallis statistical analysis was done to determine whether the expression of estrogen receptors and caspase-9 amongst groups was significantly different. The statistical analysis showed that there are significant differences amongst groups, $\mathrm{p}<0.05$. Furthermore,
Mann Whitney analysis was done to differentiate the expression of estrogen receptor and caspase- 9 between two groups, the result areas described below.

\subsection{Estrogen Receptor Expression}

Mann Whitney analysis indicated that estrogen receptor in TCP85-G and TCP125-G was significantly lower compared to that of negative group ( $\mathrm{p}<0.05$ respectively). Estrogen receptor in TCP85-G and TCP125-G had no significant difference $(\mathrm{p}>0.05)$ (Figure 1).

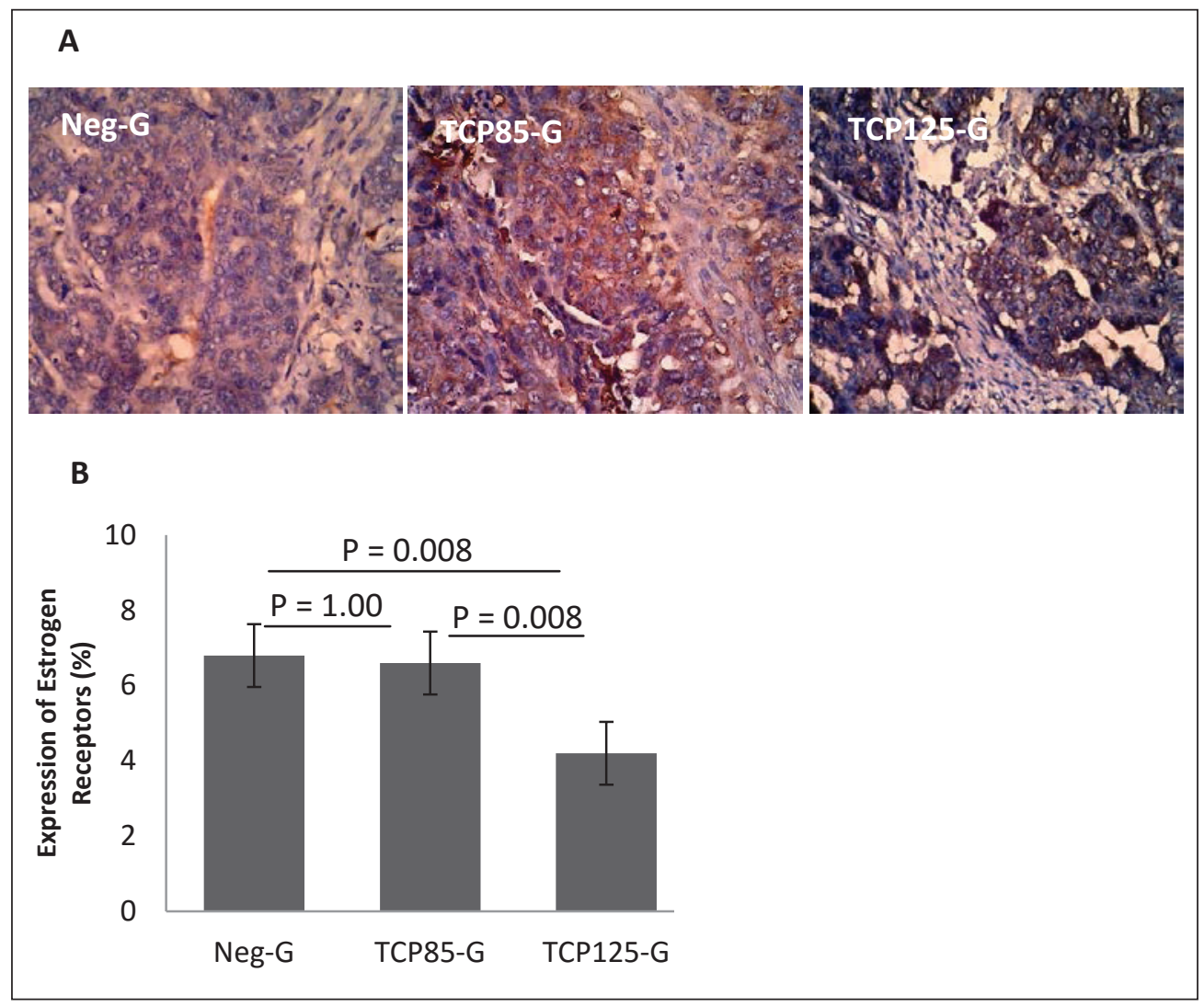

Fig. 1. A. Preparation of estrogen recetors following immunohystochemical stainned (Cytoplasmic Brown). B. Mann Withney analysis on Estrogen Receptors following TCP treatment. 


\subsection{Protein Caspase-9 Expression}

Mann Whitney analysis indicated that expression of caspase-9 in TCP85-G and Neg-G had no significance ( $\mathrm{p}>0.05)$. In contrary, expression of caspase-9 in TCP125- $G$ was significant $(p<0.05)$ than negative group (Figure 2).

\section{Discussion}

The result of the present study suggested that administration of Thyponium flageliforme in combination with Curcuma zedoaria, and Phyllanthus niruri on breast cancer in mice were able to decrease expression of estrogen receptor and increase caspase- 9 in adenocarcinoma cells. Caspase- 9 is an enzyme from the family of cysteine proteases and it activates caspase- 3 as an effectors caspase. Accordingly, when caspase- 9 is active invariably it is followed by increase in caspase- 3 activity and then apoptosis as previously reported ${ }^{23}$.

The result of the present study has also supported the theory that, apoptosis is a process triggered by death signal induction derives from both internal and external milieu, inducing mitochondrial membrane to release cytochrome-c. Cytochrome-c holoform along with apaf-1, procaspase-9, and Adenosintriphosphat (ATP) to form apoptosomedeath complex, that proteolitically convert procaspase- 9 to caspase- 9 , and then activate caspase- 7 , caspase- 6 , caspase- 3 , and finally induce DNA fragmentation and cell death ${ }^{25}$. On the other hand, apoptosis can be prevented by Bcl-2 (a protein anti apoptosis) through releasing cytochrome-c and diablo/ Smac, an Inhibitor Apoptosis Protein (IAP) binding, originated from mitochondria. Once diablo/Smac is released to cytoplasm, it immediately binds IAP, activate apoptosome and caspases, and then cellular apoptosis ${ }^{26}$.

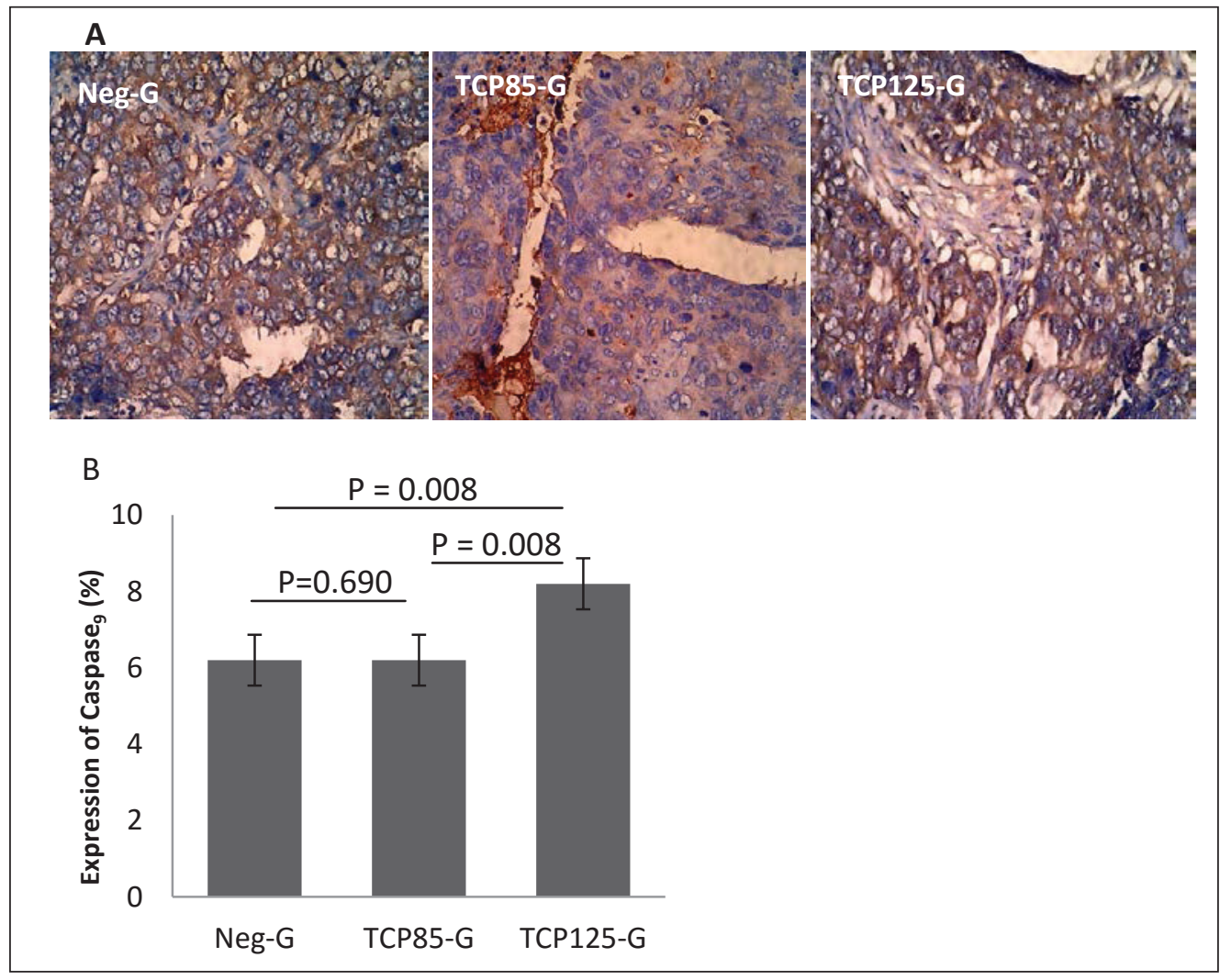

Fig. 2. A. Preparation of Caspase-9 following Immunohystochemical stainned (Cytoplasmic Brown). B. Mann Withney analysis on Caspase-9 following TCP Treatment. 
In addition, Bcl-2 via dead associated protein 6 (Daxx) also bind FADD and TRADD in order to inhibit further apoptosis signal cascade ${ }^{10}$. This result is also in line with our previous study ${ }^{9}$, indicating that treatment with TCP 85 and $125 \mathrm{mg}$ dosage were able to reduce tumor volume, expression of $\mathrm{Ki}-67$, as a marker of cellular proliferation, or increased expression of caspase-3 that serve as executioner for cellular apoptosis. The apoptosis effect of TCP on breast cancer was attributable to numerous substances contained in TCP such as terpenoids, phenylpropanoids, flavonoids, and sesquiterpenes that have been proven to possess an antitumor activity ${ }^{27}$. Flavonoids particularily are able to induce apoptosis mediated by the release of cytochrome-c to the cytosol, by processing of procaspase- 9 , and through a caspase-3dependent mechanism ${ }^{23}$. Flavonoids decrease caspase- 9 and increase cellular apoptosis by the increase in expression of Bax and decrease in Bcl-2 expression ${ }^{24}$. Flavonoids in particular might be bound by tumor cell membrane receptors, then activate some caspases in the upstream position or initiator caspases such as caspase- 2 and caspase- 8 - caspase-12, and then stimulate another caspases in downstream position or effectors caspases including caspase-3, caspase- 6 and caspase-7 to apoptosis execution. As reported, flavonoid has been proven capable of decreasing the expression of $\mathrm{Bcl} 2$ and otherwise increasing Bax expression ${ }^{24}$. In the intrinsic pathway integrity of mitochondrial membrane stability is controlled by a balance between the antagonistic actions of the proapoptotic and antiapoptotic members of the Bcl-2 family ${ }^{10,27}$.

The result of the present study also indicated that treatment of TCP125 mg capable of reducing estrogen receptor expression. In estrogen receptor positive breast cancer cells, estrogen stimulates proliferation is through the acceleration transition of G1- to S-phase. This induction is mediated by up regulation of c-myc, which controls expression of cyclin D1 in concert with activation of cyclin-dependent kinase and phosphorylation of retinoblastoma protein ${ }^{10}$. Estrogen also rapidly activates cyclin E-CDK2 complexes, accelerating the G1-to-S transition. In addition, estrogen also has an independent transcription directly interacts with a number of proteins such as $\mathrm{c}$-Src, the p85 subunit of Phosphoinositide 3-Kinase (PI3K), caveolin 1, and modulator of non-genomic activity of estrogen receptor, epidermal growth factor receptor, insulin-like growth factor receptor 1, and HER2. Consequently, activities of PIP2-phospholipase C, the Mitogen Activated Protein Kinase (MAPK), and PI3K/Akt pathways are increased rapidly. Furthermore, estrogen is a most potent inhibitor of apoptosis and regulates the expression of several apoptotic proteins $\mathrm{Bcl}-2$ in several types of breast cancer cells ${ }^{10,28}$. Moreover, estrogen also cross talk with IGF-1 in order to regulate a set of genes that affect breast cancer proliferation and apoptosis ${ }^{28,29}$. There are growing evidences that flavonoids, beside its ability to suppressing tumor cell proliferation through release of cytochrome-c to the cytosol also capable of decreasing estrogen receptors. However, estrogen receptor expression in the present study was decreased possibly by the flavonoids in TCP. Previous reports indicate that flavonoids and flavopiridolmodulate haematopoietic cell line growth and apoptosis in acute lymphoblastic leukemia and mieloidleukemia through interaction with type II estrogen binding sites ${ }^{10,30}$, despite their exact mechanism remain unclear, therefore further research is needed.

\section{Conclusion}

Combination of Thyponium flageliforme, Curcuma zedoaria, Phyllanthus nirurican reduce tumor volume, decrease the estrogen receptor and increase the expression of caspase- 9 .

\section{Acknowledgment}

The authors would like to thank the Directorate of Higher Education for funding this study. Also, the Authors would like to acknowledge Dr. Puspita Ekawuyung, MSi and Slamet laboratory of Medical Faculty, University of Indonesia for their valuable contributions.

\section{Conflict of Interest}

The authors report no conflicts of interest. The authors alone are responsible for the content and writing of the paper. 


\section{References}

1. DeSantis CE, Bray F, Ferlay J, Tieulent JL, Anderson BO, Jemal A. International variation in female breast cancer incidence and mortality rates. Cancer Epidemiology, Biomarkers and Prevention. 2015; 24(10):1495-506. Crossref. PMid:26359465

2. Ferlay J, Soerjomataram I, Ervik M, et al. Cancer incidence and mortality worldwide: sources, methods and major patterns in GLOBOCAN 2012. Int J Cancer. 2015; 136(5):E359-86. Crossref. PMid:25220842

3. Pusat Data dan Informasi Kementerian Kesehatan RI. Situasi Penyakitkanker. Buletin Jendela Data dan Informasi Kesehatan. Semester 1, 2015.

4. Strumfa I, Vanags A, Abolins A, Gardovskis J. Pathology of breast cancer: From classic concepts to molecular pathology and pathogenesis. Acta Chirurgica Latviensis. 2012; 12(1):59-66. Crossref.

5. Jemal A, Siegel R, Ward E, Hao Y, Xu J, Murray T, Thun MJ. Cancer statistics, 2008, CA. Cancer J Clin. 2008; 58(2):71-96. Crossref. PMid:18287387

6. Bombonati A, Sgroi DC. The molecular pathology of breast cancer progression. J Pathol. 2011; 223(2):307-17. Crossref. PMid:21125683 PMCid:PMC3069504

7. Berry DA, Cronin KA, Plevritis SK, et al. Effect of screening and adjuvant therapy on mortality from breast cancer. N Engl J Med. 2005; 353(17):1784-92. Crossref. PMid:16251534

8. Brenner H, Stegmaier C, Ziegler H. Recent improvement in survival of breast cancer patients in Saarland, Germany. British Journal of Cancer. 1998; 78(5):694-7. Crossref. PMid:9744513 PMCid:PMC2063047

9. Chodidjah C, Widayati E, Nasihun T. Treatment of Thyponium flageliforme in combination with Curcuma zedoaria, and Phyllanthus niruri synergistically enhances apoptotic and anti-proliferative effect on breast cancer. Journal of Natural Remedies. 2017; 17(1):1-8. Crossref.

10. Wambi JSL, Jordan VC. Estrogen regulation of apoptosis: How can one hormone stimulate and inhibit? Breast Cancer Research. 2009; 11(3):1-12.

11. Ghartey Jnr FN, Anyanful A, Eliason S, Adamu SM, Debrah S. Pattern of breast cancer distribution in ghana: A survey to enhance early detection, diagnosis, and treatment. International Journal of Breast Cancer. 2016; 3645308:1-9. Crossref. PMCid:PMC5007313

12. Schacter JL, Henson ES, Gibson SB. Estrogen regulation of anti-apoptotic bcl-2 family member mcl-1 expression in breast cancer cells. PLoS ONE. 2014; 9(6):e100364. Crossref. PMid:24971890 PMCid:PMC4074091

13. Cui J, Shen Y, Li R. Estrogen synthesis and signaling pathways during aging: From periphery to brain. Trends in Molecular Medicine. 2013; 19(3):197-209. Crossref. PMCid:PMC3595330

14. Brisken C, O'Malley B. Hormone action in the mammary gland. Cold Spring Harb Perspect Biol. 2010; 2(12): a003178. Crossref. PMid:20739412 PMCid:PMC2982168

15. Lerner LJ, Jordan VC. The development of antiestrogens for the treatment of breast cancer. Cancer Res. 1990; 50(14):4177-89. PMid:2194650

16. BeatsonGT. On the treatment of inoperable cases of carcinoma of the mamma: suggestions for a new method of treatment with illustrative cases. Lancet. 1896; 148(2):162-5. Crossref.

17. Farvid MS, Eliassen AH, Cho E, Liao X, Chen WY, Willett WC. Dietary fiber intake in young adults and breast cancer risk. Pediatrics. 2016; 137(3):e20151226. Crossref. PMid:26908709 PMCid:PMC4771124

18. Shi Y. Mechanisms of caspase activation and inhibition during apoptosis. Mol Cell. 2002; 9(3):459-70. Crossref.

19. Hu Q, Wu D, Chen W, Yan Z, Shi Y. Proteolytic processing of the caspase- 9 zymogen is required for apoptosomemediated activation of caspase-9. The Journal of Biological Chemistry. 2013; 288(21):5142-7. Crossref. PMid:23572523 PMCid:PMC3663534

20. Lee SH, Jaganath, Wang SM, Sekaran SD. Antimetastatic effect of Phyllantuhs in human lung (A 549) and breast (MCF-7) cancer cell lines. PLoS ONE; 2011; 6(6):e20994. Crossref. PMid:21698198 PMCid:PMC3116853

21. Lakshmi S. Padmaja G, Remani P. Antitumour effects of isocurcumenol isolated from curcuma zedoaria rhizomes on human andmurine cancer cells. International Journal of Medicinal Chemistry. 2011; 253962:1-13. Crossref. PMid:27429805 PMCid:PMC4939266

22. Rahman A S M, Wahab AN, Malek ASN. In vitro morphological assessment of apoptosis induced by anti proliferative constituents from the rhizomes of Curcuma zedoaria. Evidence-Based Complementary and Alternative Medicine. 2013; 257108:1-14. Crossref. PMid:23762112 PMCid:PMC3671673

23. Wang LK, Lin-Shiau SY, Lin JK. Induction of apoptosis by apigenin and related flavonoids through cytochrome c release and activation of caspase- 9 and caspase- 3 in leukaemia HL-60 cells. European Journal of Cancer. 1999; 35(10):1517-25. Crossref. 
24. Papademetrio DL, Trabucchi A, Cavaliere V, et al. The Cathechin flavonoid reduced proliferation and induced apoptosis of murine lymphoma cells LB02 through modulation of antiapoptotic proteins. Revista Brasileira de Farmacognosia. 2013; 23(3):455-63. Crossref.

25. Widayati E, Nasihun T. Treatment of Pimpinella Alpina Molk improve oxidative stress and inhibit liver cellular apoptosis in rats following UVB irradiation: Is there any correlation? Bangladesh Journal of Medical Science. 2018; 17(1):118-28. Crossref.

26. Fuida S, Debatin KM. Extrinsic versus intrinsic apoptosis pathways in anticancer chemotherapy. Oncogene. 2006; 25(34):4798-811. Crossref. PMid:16892092

27. Lakshmi S, Padmaja G, Remani P. Antitumoureffects of isocurcumenol isolated from Curcuma zedoaria rhizomes on human and murine cancer cells. International Journal of Medicinal Chemistry. 201; 253962:1-13.
28. Arpino G, Wiechmann L, Osborne CK, Schiff R. Crosstalk between the estrogen receptor and the HER tyrosine kinase receptor family: molecular mechanism and clinical implications for endocrine therapy resistance. Endocr Rev. 2008; 29(2):217-33. Crossref. PMid:18216219 PMCid: PMC2528847

29. Casa AJ, Potter AS, Malik Set al. Estrogen and insulinlike growth factor-I (IGF-I) independently down-regulate critical repressors of breast cancer growth. Breast Cancer Res Treat. 2012; 132(1):61-73. Crossref. PMid:21541704 PMCid:PMC3936881

30. Larocca LM, Teofili L, Maggiano N, Piantelli M, Ranelletti FO, Leone G. Quercetin and the growth of leukemic progenitors. Leuk Lymphoma. 1996; 23(1-2):49-53. Crossref. PMid:9021685 